\title{
Screening for selvskading i barne- og ungdoms- psykiatriske poliklinikker - erfaringer fra rekruttering til en randomisert kontrollert studie
}

\author{
Ved Berit Grøholt, Egil Haga, Anita Johanna Tørmoen, Maria Ramberg og Lars Mehlum
}

\begin{abstract}
I forbindelse med en randomisert kontrollert behandlingsstudie ble 5 poliklinikker involvert i screening av unge over 12 år for selvskading. Av 1999 henviste unge ble 25 inkludert i behandlingsstudien. Vi ønsket å studere screeningsprosessen.

$47 \%$ ble stilt det aktuelle screeningspørsmålet om de hadde skadet seg selv. Av disse 987 svarte 241 ja $(24,4 \%)$. Mange tilfredsstilte ikke inklusjonskriterier eller ønsket ikke å være med, og 85 ble henvist til prosjektet. Av disse gjennomgikk 36 en grundig vurdering. Det var mange likheter mellom de 241 og de 25 som til slutt ble inkludert: Det som skilte dem var henvisning for selvskade, antall selvskader, antall henvisningsgrunner.

Tross tett oppfølging fra prosjektet var screeningen langt fra komplett. Noen av poliklinikkene screenet flere enn de andre, men andel som ble fanget opp av prosjektet varierte lite mellom poliklinikkene. Klinisk skjønn ble trolig brukt med hell, men med over $24 \%$ som selv-skader bør alle få screeningsspørsmål.

Konklusjon: Implementering av rutiner er ikke enkelt. De som til slutt ble inkludert, skilte seg lite fra andre som selvskader. Det som skiller dem ut er et høyt lidelsestrykk, uttrykt ved mange selvskadinger, mange grunner for henvisning. og oftest henvisning for internaliserende lidelser.
\end{abstract}

Five outpatient clinics were engaged in screening referred patients 13-17 year of age, for deliberate self-harm, to a randomized controlled treatment study. Of 1999 patients referred, 25 were finally included. We wanted to study the screening process.

The screening included 987 (47\%). Self-harm was confirmed by 241 (24.4\%). Of these inclusion criteria seemed fulfilled and inclusion accepted for 86 . Of these 36 were thoroughly evaluated. Compared to the 241 , the 25 had selfharmed more often and were more often referred for self-harm and for more than one reason. In spite of close monitoring from the project, the screening was far from complete. The clinics included from $34 \%$ to $77 \%$ of referrals, but the percentage of referred patients reporting selfharm differed insignificantly between clinics. Clinical judgment was probably used with some success, but with more than $24 \%$ confirming self-harm, every patient above 12 year should be asked about self-harm.

Conclusion: Implementation of new routines is not easy. Those who were included did not differ much from those confirming self-harm. The included patients seemed to have a high level of distress, as they had self-harmed more often, more reasons for referral were given, and they were more often referred for internalizing problems.
I "Nasjonale retningslinjer for forebygging av selvmord i psykisk helsevern" lyder det første punktet i "anbefalinger og rettslige krav" slik: "Alle pasienter som kommer i kontakt med psykisk helsevern bør kartlegges for selvmordsrisiko. Pasienter bør spørres om de har eller har hatt selvmordstanker eller selvmordsplaner og om de noen gang har gjort selvmordsfors $\emptyset$. Kartlegging bør gjøres ved kontaktetablering og bør dokumenteres." (Helsedirektoratet, 2009).

Dette er et krav som er vel kjent i klinikken. Da fem barne- og ungdomspsykiatriske poliklinikker ble med i Selvskadingsstudien som er beskrevet i dette nummeret av Suicidologi, ble det etablert en prosedyre for screening av alle nyhenviste pasienter over tolv år med fokus på selvskading uavhengig av suicidal intensjon. Denne prosedyren var knyttet til at poliklinikkene dels var del av en randomisert kontrollert studie, dels at de hadde inngått avtale om å rekruttere pasienter til studien. Det vil si at initiativet til screeningsprosedyren ikke kom som et obligatorisk krav fra klinikkledelsen, slik det vanligvis skjer ved endring av rutiner. Strategiene for implementeringen kom heller ikke fra klinikkledelsen, men direkte fra ledelsen av studien. I denne artikkelen vil vi beskrive erfaringer fra denne screeningen, i forhold til å rekruttere pasienter til å delta i den randomisert kontrollerte studien. Videre vil vi drøfte om en slik screening burde bli et like naturlig krav til medarbeidere i psykisk helsevern som kravet om kartlegging av selvmordsatferd i de nasjonale retningslinjene sitert over.

Selvskadingsstudien er en omfattende randomisert kontrollert klinisk behandlingsstudie som har som målsetting å undersøke hvorvidt dialektisk atferdsterapi har bedre effekt enn forsterket vanlig behandling i barne- og ungdomspsykiatrisk poliklinikk for ungdom i alderen12-18 år. For at ungdommen skulle komme med $\mathrm{i}$ studien måtte de ha skadet seg selv med vilje flere ganger (Mehlum et al., 2014), og siste selvskadingsepisode måtte ha funnet sted i løpet av de siste fire månedene. I tillegg til å ha gjentatt selvskading måtte deltakerne også oppfylle to kriterier (eventuelt ett kriterium pluss to subterskel-kriterier) for diagnosen emosjonelt ustabil personlighetsforstyrrelse. For å få diagnosen kreves minst fem kriterier oppfylt. Med selvskading menes i denne sammenhengen det samme som Villet egenskade i ICD 10 og "Deliberate self-harm" (DSH) i engelskspråklig litteratur. Villet egenskade, eller her "selvskading", omfatter alle selvskadende handlinger uavhengig av grad av suicidal intensjon. I denne artikkelen vil vi omtale de som bekreftet villet egenskade i screeningen som "unge som selvskader". Selv om et problem er utbredt og mange synes å trenge hjelp for det aktuelle problemet, er det ofte vanskelig få mange nok deltagere i behandlingsstudier (Donovan, Paramasivan, de Salis, \&t Toerien, 2014). $\AA$ innføre eller kreve nye prosedyrer i forbindelse med et forskningsprosjekt går ikke alltid knirkefritt. I de siste årene har det kommet omfattende litteratur om problemer med å innføre nye rutiner (RycroftMalone et al., 2013). De følgende faktorene kan bidra til å gjøre slik implementering vanskelig, ifølge litteraturen:

1. Klinikere ønsker ikke å gi slipp på gamle rutiner, 2. Forskjellige profesjoner kan ha ulik tilnærming til et problem og implementering av nye rutiner kan komplisere dette, 3. Det er viktig å ha et "eierskap" til det nye som skal implementeres og slikt eierskap kan mangle, 4. Det kan være problemer med kommunikasjonen mellom de som ønsker endring og de som skal endres, 
5. Det kan være mange konkurrerende prioriteringer i den kliniske hverdagen, og 6. Institusjoner har på forhånd ulike rutiner som kan påvirke implementeringen i positiv eller negativ retning (Rycroft-Malone et al., 2013). ^ innføre et screeningspørsmål kan synes som en liten endring, men erfaring tilsier at noen av de nevnte problemene vil spille seg ut i større eller mindre grad.

Når randomisert kontrollerte studier som Selvskadingsstudien startes opp, innføres det en sammensatt rekrutteringsprosess med kriterier for deltakelse som vil føre til at bare en mindre gruppe av de screenede personene får tilbud om å delta i studien. Kriteriene for deltagelse i Selvskadingsstudien er beskrevet over. I det følgende vil vi forsøke å gi et bilde av denne rekrutteringsprosessen som starter med selve screeningen og som ender opp med at en mindre gruppe inkluderes i prosjektet. I første trinn vil vi se på hvor mange pasienter som faktisk ble screenet. Så vil vi sammenlikne de som bekreftet å ha selvskadet med de som ikke bekreftet selvskading. Deretter vil vi beskrive karakteristika ved de unge pasientene i trinnene i prosessen fram til inklusjon i studien (se figur 1).

\section{Metode}

Fem poliklinikker i Oslo-området deltok i screeningen. To av poliklinikkene hadde ansatte som deltok i DBT-behandlerteam i studien, de tre andre deltok gjennom å rekruttere pasienter og gjennom å utføre "behandling som vanlig". Poliklinikkene rapporterte antall henvisninger i aldersgruppen over tolv år i perioden de gjennomførte screeningen. Opplysninger om de som ble screenet omfattet kjønn, alder, henvisningsgrunn og hva de svarte på screeningspørsmålene. I denne studien lød det første spørsmålet slik: "Har du noen gang med vilje tatt en overdose (f.eks. piller eller annen medisin), eller forsøkt å skade deg selv på noen måte (som å kutte eller skjære deg)?" De som svarte ja ble spurt om antall selvskadingsepisoder, og om det var mindre enn fire måneder siden siste selvskadingsepisode.

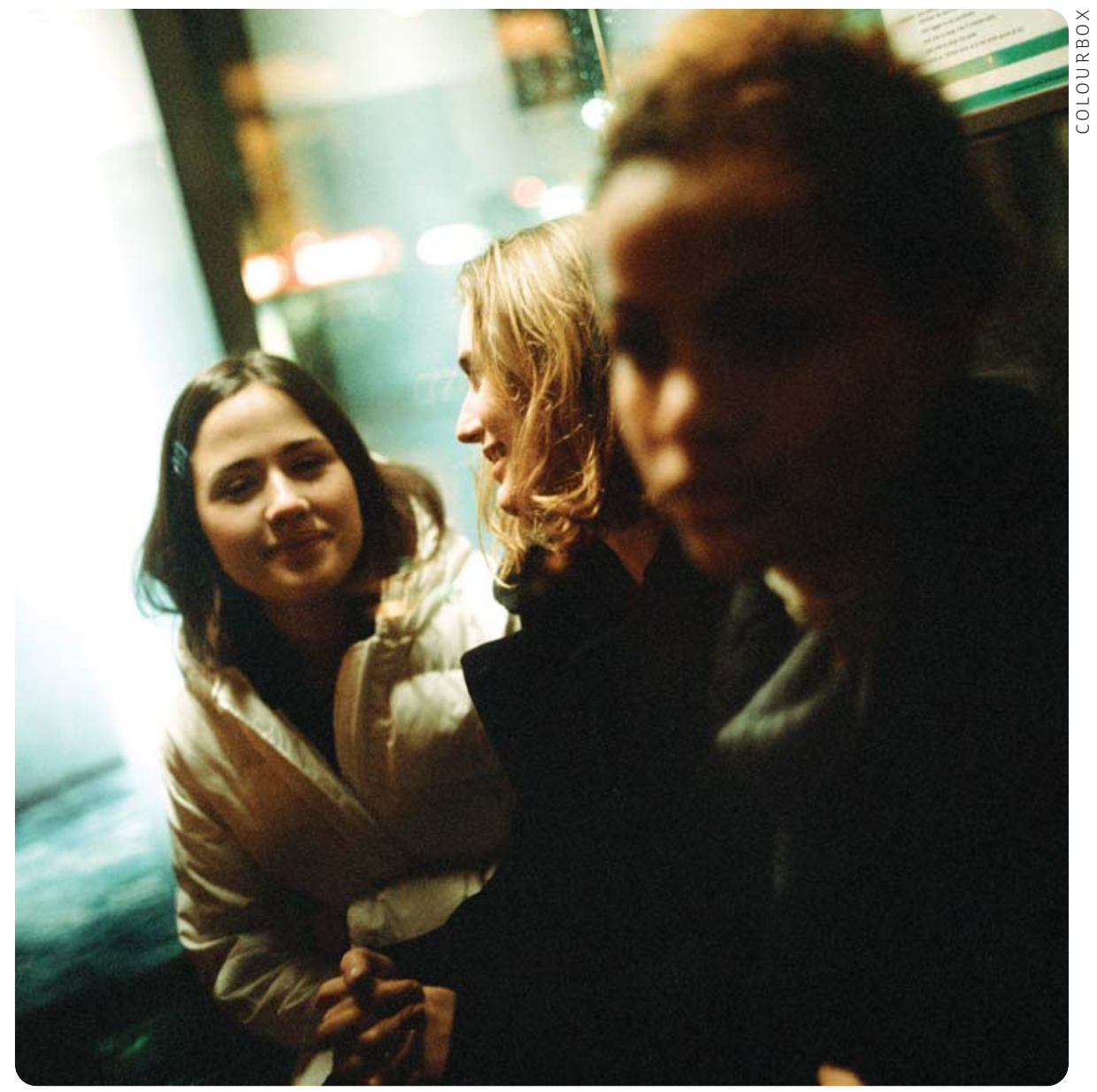

De ble også bedt om å beskrive hva de gjorde for å skade seg selv. Alle metoder for selvskading ble regnet med: Dunke hodet, kutte seg, brenne seg, skålde seg, holde sår åpne, svelge gjenstander. Ved positiv screening gjaldt klinikkens egne rutiner for pasientsikkerhet. For å styrke sikkerheten ytterligere gjennomførte prosjektet undervisning om vurdering og klinisk håndtering av selvmordsrisiko for alle behandlerne i BUP-er som deltok i prosjektet. Prosjektledelsen utarbeidet også en særskilt sikkerhetsprotokoll som alle behandlere i prosjektet fikk utlevert og ble bedt om å følge.

Screeningen ble gjennomført fra og med mars 2008 til og med mars 2012. Prosedyren ble innført og fulgt opp i samarbeid med lederne for de fem BUP-enhetene. Koordinator i prosjektet (Egil Haga) hadde jevnlig (ca. to ganger per måned) kontakt med den kontoransatte ved hver enhet som hadde fått ansvaret for de praktiske sidene ved screeningprosedyren lokalt.
Prosjektledelsen hadde ett møte per år med alle klinikerne i hver enkelt enhet for å diskutere ulike sider ved screeningen, og med formål å vedlikeholde informasjon og motivere for gjennomføring. Betydningen av screeningsystemet ble også understreket i møter mellom prosjektledelsen og de fem BUP-lederne i regelmessige møter gjennom hele prosjektets varighet. Da screeningen hadde pågått i litt over ett år ble det i tillegg innført en rutine som innebar at prosjektkoordinator ga månedlig tilbakemelding til enhetslederne om antall screenede i forhold til antall henviste.

Henvisningsgrunner framgår av tabell 2. I alle tilfeller dreide det seg om mistanke om ett av problemene, for eksempel "mistanke om depresjon", selv om det i tabellen bare står "depresjon". Noen henvisningsgrunner ble plassert blant "andre grunner" fordi de forekom sjelden. Det dreide seg om mistanke om Tourettes syndrom, Hemmet atferd og Symptomer pga. somatisk lidelse. 
Tabell 1: Pasienter henvist til de fem poliklinikkene i perioden og andel som ble screenet. Andelene i \% som bekreftet selvskading er oppgitt både blant de screenede og blant de henviste.

\begin{tabular}{|c|c|c|c|c|c|}
\hline $\begin{array}{l}\text { Henviste } \\
\text { pasienter pr. } \\
\text { poliklinikk } n \\
\mathrm{~N}=1999\end{array}$ & $\begin{array}{l}\text { Antall og andel } \\
\text { screenede blant } \\
\text { henviste } n(\%) \\
n=987\end{array}$ & $\begin{array}{l}\text { Antall og andel } \\
\text { blant screenede som } \\
\text { ikke svarte } n(\%) \\
n=57\end{array}$ & $\begin{array}{l}\text { Antall og andel } \\
\text { med positiv } \\
\text { screen } n(\%) \\
n=241\end{array}$ & $\begin{array}{l}\text { Antall og andel } \\
\text { av henviste med } \\
\text { positiv screen (\%) } \\
n=241\end{array}$ & $\begin{array}{l}\text { Antall og andel } \\
\text { henviste inkludert } \\
\text { i prosjektet } n(\%) \\
n=25\end{array}$ \\
\hline A. 312 & $239(77)$ & $18(7,5)$ & $38(15,9)$ & 12,2 & $3(0,9)$ \\
\hline B. 475 & 266 (56) & $7(2,6)$ & $60(22,6)$ & 12,6 & $9(1,9)$ \\
\hline C. 393 & $132(34)$ & $3(2,3)$ & $37(28,0)$ & 9,4 & $3(0,7)$ \\
\hline D. 429 & $172(40)$ & $27(15,7)$ & $50(29,0)$ & 11,7 & $3(0,6)$ \\
\hline E. 390 & $178(46)$ & $2(1,1)$ & $58(32,5)$ & 14,9 & $7(1,8)$ \\
\hline 1999 & 987 (49) & $57(5,8)$ & $241(24,4)$ & 12,1 & $25(1,3)$ \\
\hline
\end{tabular}

Vi samlet opplysninger om hvordan prosessen fra henvisning til poliklinikk til inkludering i Selvskadingsprosjektet foregikk: Hvem hadde positiv screen for selvskade av de som ble screenet, hvem av dem som hadde positiv screen for selvskade ble ekskludert fra prosjektet i første runde, hvem av dem ble utredet med tanke på inklusjon og hvem av dem ble til slutt inkludert i studien. Årsaken til at de unge ikke gikk videre i prosessen ble notert så godt det lot seg gjøre, men mangler for noen.

Vi har sammenliknet henvisningsgrunner for de ulike gruppene i prosessen ved hjelp av krysstabell med eksakt statistikk (Fishers eksakte test). Gjennomsnittsverdier er sammenliknet ved hjelp av t-test for uavhengige grupper.

\section{Resultater}

\section{Poliklinikkenes screening}

Tabell 1 viser at de fem poliklinikkene fikk henvist i alt 1999 pasienter over tolv år i det aktuelle tidsrommet. Poliklinikkene oppnådde å screene mellom $34 \%$ og $77 \%$ av de henviste pasientene. De to poliklinikkene som screenet størst andel, hadde ansatte i DBT-behandlerteam. I poliklinikker som screenet en stor andel av pasientene var det lavest andel som hadde positiv screen for selvskading. I poliklinikken med høyest prosent screenede (77 \%) svarte $17,2 \%$ at de hadde selvskadet, mens poliklinikken som screenet $34 \%$ hadde en positiv screen på $28,7 \%$. Hvis vi beregner andel med positiv screen blant alle som var henvist, var det mindre variasjon, fra $9,4 \%$ til $14,9 \%$.
Blant de 987 som ble screenet for selvskading var $58 \%$ piker, og gjennomsnittsalderen var 15,2 år $(S D=1,7)$ (gutter 15,0 år ( $S D=1.8)$, piker 15,4 år $(S D=1,6))$. Alle poliklinikkene screenet flere piker enn gutter, fra $53 \%$ til $64 \%$. Flytdiagrammet i figur 1 viser prosessen fra henvisning til poliklinikk til inklusjon i studien. I den aktuelle perioden ble til slutt 25 av de 1999 som ble henvist til poliklinikkene inkludert i studien. Frafallet skjedde på flere måter: 1012 ble ikke screenet. For noen $(n=57)$ av de 987 som ble screenet manglet informasjon om hva de svarte. De 57 hadde samme kjønns- og aldersfordeling som de 930 der informasjon var tilgjengelig, Også henvisningsgrunnene var de samme bortsett fra henvisningsgrunnen "annet" som forekom hyppig blant de 57 ( $26 \%$ vs. $12 \%$, Fisher $p=.003$ ).

Blant de som ble screenet sa 689 at de ikke hadde selvskadet. Av de 241 som bekreftet å ha selvskadet en eller annen gang i løpet av livet, ble 146 vurdert som ikke inkluderbare i prosjektet. Det var mange grunner til det, det viktigste var at de ikke hadde selvskadet de siste 4 månedene eller at de ikke hadde gjentatt selvskade. Av de 85 som fortsatt ble oppfattet som aktuelle, ble 49 ekskludert av følgende grunner: Samtykket ikke $(n=20)$, fylte ikke øvrige inklusjonskriterier $(n=10)$, ville ikke at foreldre skulle involveres $(n=7)$, fikk eller trengte annen behandling $(n=7)$, foreldrene samtykket ikke $(n=2)$ eller kunne ikke delta av praktiske grunner $(n=3)$. Av de 36 som ble utredet, ble 11 ekskludert, 4 fylte ikke kriteriene, 3 samtykket ikke, 3 trakk seg dels av praktiske grunner og 1 trakk seg av annen grunn (se figur 1). I alt var det 25 ungdommer fra de fem poliklinikkene som ble inkludert i studien. Deltakelse i studien hadde ingen innflytelse på hvorvidt den enkelte ungdom ble tilbudt behandling på poliklinikken.

\section{Henvisningsgrunner}

Vi kjente resultatet av screeningen for 930 (Figur 1). Av disse 930 manglet vi opplysninger om henvisningsgrunn for 47 , alder for 15 og kjønn for 5 . Vi sammenliknet så ungdommer med positiv screen med dem som hadde negativ screen. I tabell 2 er alle de screenende pasientene slått sammen til en gruppe uavhengig av poliklinikk. Vi ser at langt flere piker enn gutter screenet positivt for selvskading (36,9 vs. $11,2 \%$ ). Gutter som hadde positiv screen var signifikant eldre enn de guttene som hadde negativ screen (15,7 år vs. 14,8 år), men det var ingen aldersforskjell mellom gutter og jenter som hadde selvskadet.

De unge som rapporterte å ha selvskadet, hadde en overhyppighet av følgende henvisningsgrunner: mistanke om enten selvskading, depresjon, selvmordstanker eller psykisk reaksjon etter traumer. På den annen side var de i mindre grad henvist for utredning av ADHD og angst, og "andre problemer" (tabell 2).

I mange saker ble det oppgitt mer enn en henvisningsgrunn. Blant disse ungdommene var det en signifikant større andel som hadde positiv screen for selvskading $(47,2$ $\%$ vs. $32,8 \%$ ). I noen saker var det ingen henvisningsgrunn som var knyttet til ungdommen, men derimot til miljø eller familie. 
Figur 1. Flytdiagram: Prosessen fra 1999 henviste til 25 inkludert i behandling $\mathrm{i}$ prosjektet.

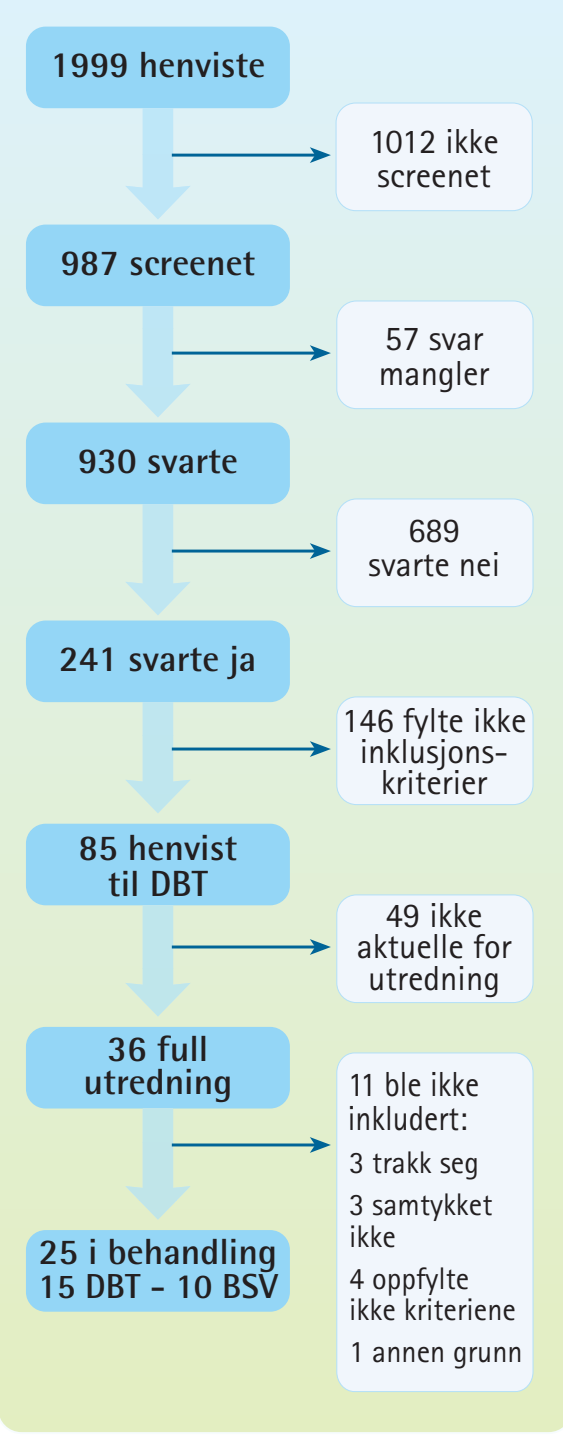

Men også blant ungdommer uten slik henvisningsgrunn var det noen som hadde positiv screen. Henvisningsgrunner knyttet til miljø eller familie var oppgitt for 88 $(9,4 \%)$ av de screenede ungdommene og det var ingen forskjell mellom de med og uten selvskading.

Hvilke unge ble inkludert i trinnene i rekrutteringsprosessen?

Vi undersøkte om det skjedde signifikante endringer i karakteristika ved ungdommene etterhvert som utvalget ble stadig snevrere i seleksjonsprosessen for inklusjon i studien.

Tabell 2. Sammenlikning mellom de som rapporterte å ha selvskadet og de som ikke hadde selvskadet blant screenede ungdommer etter alder, kjønn og henvisningsgrunn (henvisn.gr.).

\begin{tabular}{c|c|c|c|}
$\mathrm{N}=\mathbf{9 3 0}$ & $\begin{array}{c}\text { Positiv } \\
\text { screen }\end{array}$ & $\begin{array}{c}\text { Negativ } \\
\text { screen }\end{array}$ & $\begin{array}{c}\text { Alle } \\
\text { screenede } \\
\mathrm{n}=\mathbf{2 4 1}\end{array}$ \\
& $\mathrm{n}=\mathbf{6 8 9}$ & $\mathrm{N}=\mathbf{9 3 0}$
\end{tabular}

Gj.snitt (SD)* Gj.snitt (SD) Gj.snitt (SD) p-verdi

\begin{tabular}{|l|r|r|r|r|r|r|r|r|}
\hline Alder (år) $n=920$ & 15,5 & $(1,7)$ & 15,1 & $(1,6)$ & 15,2 & $(1,7)$ & $F=3,6$ & $<, 001$ \\
\hline Alder gutter $n=395$ & 15,7 & $(1,7)$ & 14,8 & $(1,8)$ & 15,0 & $(1,8)$ & $F=1,9$ &, 002 \\
\hline Alder piker $n=535$ & 15,5 & $(1,6)$ & 15,3 & $(1,6)$ & 15,4 & $(1,6)$ & $F=, 37$ &, 202 \\
\hline Kjønn & $\mathbf{n}$ & $(\%)$ & $\mathbf{n}$ & $(\%)$ & $\mathbf{n}$ & $(\%)$ & & \\
\hline Piker & 198 & $(36,9)$ & 342 & $(63)$ & 540 & $(58)$ & $<, 001$ \\
\hline Gutter & 43 & $(11,2)$ & 342 & $(89)$ & 385 & $(42)$ & \\
\hline Henvisn.gr. ungdom & $\mathbf{n}$ & $(\%)$ & $\mathbf{n}$ & $(\%)$ & $\mathbf{n}$ & $(\%)$ & \\
\hline Flere grunner & 109 & $(47,2)$ & 214 & $(32,8)$ & 323 & $(66,6)$ & $<, 001$ \\
\hline Depresjon & 125 & $(52,1)$ & 242 & $(35,2)$ & 367 & $(49,6)$ & $<, 001$ \\
\hline Spiseforstyrrelse & 21 & $(8,8)$ & 43 & $(6,3)$ & 63 & $(6,8)$ &, 187 \\
\hline Angst & 15 & $(6,4)$ & 133 & $(20,4)$ & 148 & $(16,7)$ & $<, 001$ \\
\hline ADHD & 18 & $(7,5)$ & 91 & $(13,2)$ & 109 & $(11,8)$ &, 019 \\
\hline Atferd & 16 & $(6,7)$ & 62 & $(9,0)$ & 78 & $(8,4)$ &, 280 \\
\hline Skolevegring & 24 & $(10,0)$ & 87 & $(12,7)$ & 111 & $(12,0)$ &, 300 \\
\hline Tvang & 5 & $(2,1)$ & 28 & $(2,1)$ & 47 & $(5,0)$ &, 163 \\
\hline Bipolar & 10 & $(4,1)$ & 28 & $(4,1)$ & 38 & $(4,1)$ & 1,0 \\
\hline Psykose & 2 & $(0,8)$ & 11 & $(1,6)$ & 13 & $(1,4)$ & \\
\hline Selvmordstanker & 18 & $(7,5)$ & 8 & $(1,2)$ & 26 & $(2,8)$ & $<, 001$ \\
\hline Annet & 16 & $(6,6)$ & 94 & $(13,7)$ & 100 & $(10,8)$ &, 003 \\
\hline PDD & 11 & $(1,6)$ & 2 & $(0,8)$ & 13 & $(1,4)$ &, 532 \\
\hline Selvskading & 48 & $(20,0)$ & 0 & $(0)$ & 48 & $(5,2)$ & $<, 001$ \\
\hline Ingen henvisn.gr. & 2 & $(1,0)$ & 5 & $(1,5)$ & 7 & $(1,4)$ & 1,00 \\
\hline Miljøproblem & $\mathbf{n}$ & $\mathbf{( \% )}$ & $\mathbf{n}$ & $(\%)$ & $\mathbf{n}$ & $(\%)$ & \\
\hline Familieproblem & 26 & $(81,2)$ & 41 & $(73,2)$ & 67 & $(76,1)$ &, 447 \\
\hline Miljøproblem & 4 & $(12,5)$ & 7 & $(12,5)$ & 11 & $(12,5)$ & 1,00 \\
\hline Skoleproblem & 7 & $(21,9)$ & 19 & $(33,9)$ & 26 & $(29,5)$ &, 332 \\
\hline & & & & & & \\
\hline
\end{tabular}

*SD = standardavvik (standard deviation)

Som det framgår av tabell 3 var det små forskjeller når det gjaldt selvskademetode. Vi sammenliknet gruppen $(n=25)$ som ble inkludert i studien med de som ikke ble inkludert blant de 241 som hadde positiv screen. Skademetodene som ble brukt var ikke forskjellige, men de som ble inkludert hadde skadet seg oftere (de inkluderte $63,2 \%$, de screenede $31,0 \%, p=, 009$ ). Henvisningsgrunnene var stort sett de samme med ett unntak; de som ble inkludert ble oftere henvist pga. selvskading $(56,0 \%$ vs. $15,7 \%, p<, 001)$. 


\section{Drøfting}

Blant alle som ble screenet for selvskading i BUP ble bare et fåtall inkludert i studien. Det var allikevel ikke mange forskjeller når det gjelder selvskademetode og henvisningsgrunn mellom de 241 unge som hadde positiv screen og de 25 som til slutt ble inkludert.

Bare tre forhold skiller seg ut; de som ble inkludert hadde oftere vært henvist for selvskading, de hadde blitt henvist av mer enn en grunn og de hadde selvskadet mange ganger. Dette dreier seg mer om kvantitative enn kvalitative forskjeller, og det er rimelig å anta at et høyt lidelsestrykk mer enn spesifikke vansker karakteriserer de som ble inkludert i prosjektet i forhold til de som hadde positiv screen og ikke ble inkludert.

Halvparten av pasientene som var aktuelle for screening ble ikke screenet. Det kan være mange grunner til at screeningandelen ikke ble høyere.
Stort arbeidspress kan gjøre det vanskelig for mange klinikere å huske å etterleve nye rutiner, tross systematisk oppfølging fra et prosjekt (Rycroft-Malone et al., 2013). Man kan spekulere på om behandlerne kunne ha lav opplevelse av eierskap til prosjektet. Riktignok var alle de fem poliklinikkene involvert i prosjektet i en viss grad, men de to poliklinikkene som hadde høyest screeningprosent var sterkest involvert med deltakelse av egne behandlere i den kliniske delen av prosjektet. Dette styrker hypotesen om at eierskap er et viktig element i implementering (Rycroft-Malone et al., 2013). Poliklinikken med høyest screeningprosent hadde i tillegg innlemmet screeningen i en eksisterende rutine, noe som sannsynligvis også forklarer den høye screeningprosenten. Med andre ord la deres tidligere praksis til rette for nye rutiner (RycroftMalone et al., 2013).

Tabell 3. Antall selvskadingsepisoder og selvskadingsmetode i gruppene fra screeningsprosessen (de som svarte ja $\mathrm{N}=241$ om selvskading, de som fylte inklusjonskriteriene ved første vurdering $N=85$, de som gjennomgikk utredning $N=36$ og de som kom i behandling $\mathrm{N}=25$ ). Henvisningsgrunner som var hyppigere blant de med selvskading enn blant de uten selvskading er også med i tabellen.

\begin{tabular}{|c|c|c|c|c|c|c|c|c|c|}
\hline \multirow[t]{2}{*}{$\begin{array}{l}\text { Henvisnings- } \\
\text { grunn }\end{array}$} & \multicolumn{2}{|c|}{$\begin{array}{l}\text { Positiv } \\
\text { screening } \\
\mathrm{N}=241\end{array}$} & \multicolumn{2}{|c|}{$\begin{array}{c}\text { Henvist } \\
\text { DBT } \\
n=85\end{array}$} & \multicolumn{2}{|c|}{$\begin{array}{l}\text { Utredet } \\
\qquad n=36\end{array}$} & \multicolumn{2}{|c|}{$\begin{array}{c}\text { I behand- } \\
\text { ling } \\
n=25\end{array}$} & \multirow[t]{2}{*}{ p-verdi* } \\
\hline & $n$ & $\%$ & $n$ & $\%$ & $n$ & $\%$ & $n$ & $\%$ & \\
\hline Selvskading & 48 & $(20,0)$ & 25 & $(29,4)$ & 17 & $(47,2)$ & 14 & $(56,0)$ & $<, 001$ \\
\hline Depresjon & 125 & $(52,1)$ & 44 & $(51,8)$ & 20 & $(55,6)$ & 14 & $(56,0)$ &, 412 \\
\hline Selvmordstanker & 18 & $(7,5)$ & 5 & $(5,8)$ & 2 & $(8,0)$ & 2 & $(11,1)$ &, 580 \\
\hline Flere henv.gr. & 109 & $(47,2)$ & 67 & $(45,3)$ & 23 & $(65,7)$ & 15 & $(62,5)$ &, 132 \\
\hline \multicolumn{10}{|l|}{ Metode } \\
\hline Kutting & 130 & $(53,7)$ & 50 & $(58,8)$ & 23 & $(63,9)$ & 15 & $(60,0)$ &, 532 \\
\hline Risping & 35 & $(14,5)$ & 13 & $(15,5)$ & 5 & $(13,9)$ & 2 & $(8,0)$ & 1,00 \\
\hline Overdose & 15 & $(6,2)$ & 4 & $(4,7)$ & 3 & $(8,3)$ & 3 & $(12,0)$ &, 657 \\
\hline Skallet hode & 11 & $(4,5)$ & 5 & $(5,9)$ & 2 & $(5,6)$ & 2 & $(8,0)$ &, 315 \\
\hline Kvelning & 6 & $(1,2)$ & 1 & $(1,2)$ & 1 & $(2,8)$ & 1 & 4,0 & .482 \\
\hline Brenning & 3 & $(0,6)$ & 2 & $(2,4)$ & 1 & $(2,8)$ & 1 & $(4,0)$ &, 279 \\
\hline Annet & 17 & $(7,0)$ & 6 & $(7,1)$ & 0 & $(0)$ & 0 & $(0)$ &, 230 \\
\hline Ukjent & 24 & $(9,9)$ & 4 & $(4,7)$ & 1 & $(2,8)$ & 1 & $(4,0)$ &, 262 \\
\hline $\begin{array}{l}\text { Mer enn } 10 \text { selv- } \\
\text { skadingsepisoder }\end{array}$ & 57 & $(23,6)$ & 28 & $(51,9)$ & 15 & $(62,6)$ & 12 & $(63,2)$ & $<, 001$ \\
\hline
\end{tabular}

*Statistisk sammenlikning (Fisher eksakt test) mellom de som ble inkludert $(n=25)$ og de som ikke ble inkludert i studien ( $n=216)$. Alle hadde rapportert selvskade $(n=241)$.

En årsak til at mange ungdommer ikke ble screenet til tross for rutinene, kan også være at klinikere kunne velge å følge sitt kliniske skjønn istedenfor å spørre alle; de kunne mene at spørsmålet ville oppleves irrelevant eller krenkende (Bongiovi-Garcia et al., 2009). Dette kan også være en medvirkende årsak til at andelen av piker blant de screenede var høy, til tross for at flere gutter blir henvist til BUP (Pedersen et al., 2008). Hvis vi går ut fra at bruk av klinisk skjønn er en av grunnene til at ikke flere er spurt, må vi se på hvor mange selvskadingsepisoder som ble avdekket. De som screenet færrest, avdekket en større prosent screen positive blant de screenede (Tabell 1). Screeningprosenten varierte mellom $34 \%$ og $77 \%$, allikevel var det liten forskjell i andelen som bekreftet selvskading blant de henviste. Selv om vi ser en svak tendens som peker mot at de som spurte flest, avdekket flest blant de henviste, kan funnene tyde på at klinikerne hadde et rimelig godt skjønn. Allikevel vet vi at klinikere trenger å støtte seg på strukturerte prosedyrer for å få tak i suicidalatferd generelt (BongioviGarcia et al., 2009; Healy, Barry, Blow, Welsh, \&t Milner, 2006), og i denne studien skulle screeningen skje ved hjelp av et konkret utformet spørsmål. Dette spørsmålet og involvering i prosjektet gjorde sannsynligvis klinikerne mer fokusert på selvskading enn de ellers ville vært. Samtidig ser vi at så mange som 10-12 \% av alle henviste og 24,5\% av de screenede pasientene rapporterte selvskading, og det i seg selv kan være en god nok begrunnelse for at alle unge bør screenes for selvskading like vel som for selvmordsatferd. Selv om klinikere har et rimelig godt skjønn, er det grunn til å tro at de sjeldnere bruker dette skjønnet når de ikke er involvert i et prosjekt som stadig tar kontakt og pålegger dem å stille et konkret spørsmål. Derfor er det rimelig å mene at alle poliklinikker og avdelinger bør spørre pasienter over tolv år om selvskading (Bongiovi-Garcia et al., 2009). 
Vi ser at de som rapporterte selvskade oftere ble henvist for flere grunner og ofte pga. mistanke om depresjon, selvmordstanker og ikke minst selvskading. Unge henvist for ADHD eller atferdsproblemer selvskadet også noe, men de fleste av dem gjorde det ikke.

Vårt inntrykk er at det ikke er spesielle typer henvisningsproblemer som preger de som selvskadet, men heller at de synes å ha et stort personlig indre lidelsestrykk, slik en ser ved internaliserende lidelser. Vi ser at angst forekommer hyppigere blant de som ikke selvskader. Angst kan ha effekt på flere måter, og det har vært hevdet at moderat angst fører til at personer ikke tør selvskade, mens sterk angst kan ha motsatt effekt og ofte fører til selvskade med intensjon om å dø (Chartrand, Sareen, Toews, \& Bolton, 2011).

Selvskadingsstudien rettet seg likevel ikke primært mot symptomlidelser knyttet til selvskading, men til emosjonell reguleringssvikt knyttet til Emosjonelt Ustabil Personlighetsforstyrrelse (EUP). En EUPdiagnose var ikke noe krav for inklusjon i prosjektet, men man krevde at minst to diagnosekriterier ble oppfylt i tillegg til kriteriet om gjentatt selvskading eller suicidalitet. Det var mange som rapporterte selvskading som ble ekskludert fordi de bare hadde skadet seg én gang, eller ikke hadde gjort det i løpet av de siste fire måneder. Men det var bare to som ble ekskludert fordi de ikke hadde EUPtrekk som nevnt over. Da var imidlertid ungdommene kommet fram til det siste trinnet av seleksjonsprosessen der diagnostiske vurderinger ble foretatt. Fra litteraturen er det kjent at selvskading er vanlig blant personer med emosjonelt ustabil personlighetsforstyrrelse (Muehlenkamp, Ertelt, Miller, \&t Claes, 2011). Vår erfaring tyder på at slike trekk (men ikke nødvendigvis full diagnose) er vanlig blant norske ungdommer som selvskader.

De 25 som til slutt ble inkludert i prosjektet skilte seg ikke mye fra hele gruppen på 241 som screenet positivt for selvskading. Den mest markante forskjellen var at de oftere ble henvist nettopp for selvskading, og at de hadde selvskadet oftere enn dem som falt fra i løpet av seleksjonsprosessen.
Vi antar at mange av de 216 som hadde positiv screen for selvskading, men ikke ble inkludert i studien, var i behov av og mottok behandling i poliklinikken de var henvist til. Det hadde vært interessant å se hva slags behandling de som ikke ble inkludert fikk, men det ligger utenfor rammen av denne artikkelen.

\section{Konklusjon}

Implementering av nye rutiner tar ofte tid, noe også dette prosjektet bekrefter. Klinisk skjønn er viktig, men ikke så viktig at det kan erstatte gode rutiner. Unge som selvskader synes å ha et høyt indre lidelsestrykk, og er ikke så ofte henvist for mistanke om utagerende eller urolig atferd. Det gjelder også de 25 som ble inkludert i studien, selv om de hadde noen symptomer, som ved personlighetsforstyrrelse, som kan oppleves utagerende og ofte involverer mellom-menneskelige konflikter.

\section{Referanser}

Bongiovi-Garcia, M. E., Merville, J., Almeida, M. G., Burke, A., Ellis, S., Stanley, B. H., ... Oquendo, M. A. (2009). Comparison of clinical and research assessments of diagnosis, suicide attempt history and suicidal ideation in major depression. J Affect Disord, 115(1-2), 183-188. doi: 10.1016/j.jad.2008. 07.026

Chartrand, H., Sareen, J., Toews, M., \&t Bolton, J. M. (2011). Suicide attempts versus nonsuicidal self-injury among individuals with anxiety disorders in a nationally representative sample. Depress. Anxiety. doi: 10.1002/da.20882 [doi]

Donovan, J. L., Paramasivan, S., de Salis, I., \& Toerien, M. (2014). Clear obstacles and hidden challenges: understanding recruiter perspectives in six pragmatic randomised controlled trials. Trials, 15, 5. doi: 10.1186/1745-6215-15-5

Healy, D. J., Barry, K., Blow, F., Welsh, D., \&t Milner, K. K. (2006). Routine use of the Beck Scale for Suicide Ideation in a psychiatric emergency department. Gen Hosp Psychiatry, 28(4), 323-329. doi: 10.1016/j.genhosppsych.2006.04.003

Helsedirektoratet. (2009). Nasjonale retningslinjer for forebygging av selvmord i psykisk helsevern. Nasjonale faglige retningslinjer.

Mehlum, L., Tørmoen, A., Ramberg, M., Haga, L., Lien, M. D., Laberg, S., ... Grøholt, B. (2014). Dialectical Behavior Therapy for Adolescents With Repeated Suicidal and Self-harming Behavior - A Randomized Trial. J Am Acad Child Adolesc Psychiatry. 53(10), 1082-1091. doi: 10.1016/j.jaac. 2014.07.003.

Muehlenkamp, J. J., Ertelt, T. W., Miller, A. L., \& Claes, L. (2011). Borderline personality symptoms differentiate non-suicidal and suicidal self-injury in ethnically diverse adolescent outpatients.

J Child Psychol Psychiatry, 52(2), 148-155. doi: 10.1111/j.1469-7610.2010.02305.x

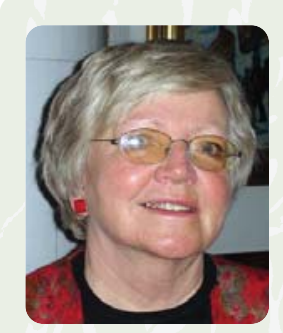

Berit Grøholt

er professor emeritus og har publisert artikler innen en rekke barnepsykiatriske emner. Hun er i dag tilknyttet Institutt for klinisk medisin og NSSF.

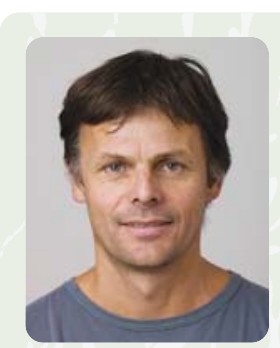

Egil Haga

er dr.philos og prosjektkoordinator for Selvskadingsstudien ved NSSF.

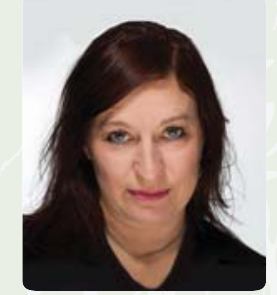

Anita Johanna Tørmoen

er forsker og DBTlærer ved NSSF.

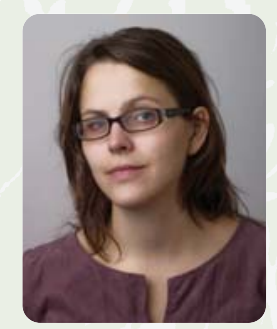

Maria Ramberg er lege i spesialisering i barne- og ungdomspsykiatri og tidligere stipendiat ved NSSF.

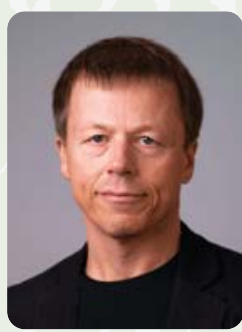

Lars Mehlum er psykiater og professor i psykiatri og suicidologi ved Universitetet i Oslo. Han er leder for NSSF og flere av senterets forskningsprosjekter, bl.a. Selvskadingsstudien Han er DBT-lærer og leder for NSSFs utdanningsprogram i Dialektisk Atferdsterapi.

Pedersen, P. B., Jensberg, H., Kalseth, J., Kaspersen, S. L., Halsteinli, V., Ose, S. O., \& Sitter, M. (2008). Samdata Sektorrapport for det psykiske helsevernet 2008. Trondheim: SINTEF.

Rycroft-Malone, J., Seers, K., Chandler, J., Hawkes C. A., Crichton, N., Allen, C., . . Strunin, L. (2013) The role of evidence, context, and facilitation in an implementation trial: implications for the development of the PARIHS framework. Implement Sci, 8, 28. doi: 10.1186/1748-5908-8-28. 